Analitika: Jurnal Magister Psikologi UMA, Vol. 11 (2) Desember (2019)

ISSN: 2085-6601 (Print), ISSN: 2502-4590 (Online)

DOI: http://dx.doi.org/analitika.v11i1.2817

\title{
ANALITIKA
}

Jurnal Magister Psikologi UMA

Available online http://ojs.uma.ac.id/index.php/analitika

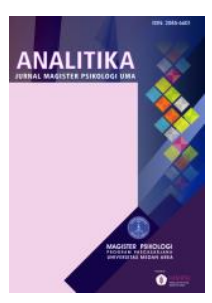

\section{Loyalitas Pelanggan Maskapai Penerbangan Ditinjau dari Kualitas Layanan dan Emotional Branding}

\section{Airlines Customer Loyalty Reviewed from Service Quality and Emotional Branding}

\author{
Novia Sari*1), Aditya Nanda Priyatama2) \& Pratista Arya Satwika ${ }^{3)}$ \\ 1) 2) 3) Program Studi Psikologi, Fakultas Kedokteran, \\ Universitas Sebelas Maret, Indonesia
}

Diterima: 20 Agustus 2019, disetujui: 26 Desember 2019, dipublish: 30 Desember 2019

*Corresponding author: E-mail: nnoviasarii@gmail.com

\begin{abstract}
Abstrak
Adanya peningkatan jumlah penumpang pesawat memicu persaingan antar maskapai penerbangan dalam menciptakan dan mempertahankan loyalitas pelanggan. Loyalitas pelanggan dapat dipengaruhi oleh berbagai faktor, diantaranya adalah kualitas layanan dan emotional branding. Oleh karena itu, penelitian ini dilakukan untuk: (1) mengetahui adanya hubungan antara kualitas layanan dan emotional branding dengan loyalitas pelanggan; (2) mengetahui adanya hubungan antara kualitas layanan dengan loyalitas pelanggan; dan (3) mengetahui adanya hubungan antara emotional branding dengan loyalitas pelanggan maskapai penerbangan. Sampel yang digunakan pada penelitian ini berjumlah 69 orang yang dipilih berdasarkan simple random sampling. Adapun instrumen penelitian yang digunakan adalah skala loyalitas pelanggan, skala kualitas layanan, dan skala emotional branding. Berdasarkan hasil analisis regresi yang dilakukan, diketahui bahwa terdapat hubungan yang signifikan antara kualitas layanan dan emotional branding dengan loyalitas pelanggan maskapai penerbangan $(\mathrm{p}=0,000 ; \mathrm{p}<0,05)$. Tingkat hubungan antara ketiga variabel tersebut tergolong sedang $(r=0,537)$ dengan sumbangan efektif sebesar $28,8 \%$. Selain itu, penelitian ini membuktikan bahwa tidak terdapat hubungan secara parsial antara kualitas layanan dengan loyalitas pelanggan maskapai penerbangan $(p=0,111 ; p>0,05)$ dan emotional branding dengan loyalitas pelanggan maskapai penerbangan $(p=0,172 ; p>0,05)$. Dengan demikian, perusahaan perlu menyediakan layanan yang berkualitas dan emotional branding secara bersama-sama agar penumpang mendapatkan kepuasan secara fisik dan psikis.
\end{abstract}

Kata kunci: loyalitas pelanggan, kualitas layanan, emotional branding

\begin{abstract}
An increasing number of aircraft passengers triggers the airline companies to compete in creating and maintaining customer loyalty. Customer loyalty can be influenced by various factors, including service quality and emotional branding. Therefore, this study was conducted to: (1) find out the relationship between service quality and emotional branding with customer loyalty; (2) knowing the relationship between service quality and customer loyalty; and (3) knowing the relationship between emotional branding and airline customer loyalty. The number of samples used in this study was 69 people who were selected by simple random sampling. The research instruments used were the scale of customer loyalty, service quality scale, and emotional branding scale. Based on the results of the regression analysis, it is shown that there is a significant relationship between service quality and emotional branding with airline customer loyalty $(p=0,000 ; p<0,05)$. The level of the correlation between these variables is classified as moderate $(r=0,537)$ with the effective contribution by $28,8 \%$. In addition, this research proves that there is no relationship between service quality and airline customer loyalty partially $(p=0,111 ; p>0,05)$. Similar to the result of the third hypothesis test, the study reveals no partial relationship between emotional branding and airline customer loyalty $(p=0,172 ; p>0,05)$. Therefore, the airlines need to provide quality services and emotional branding simultaneously so that the passengers can experience the physical and psychological satisfaction.
\end{abstract}

Keywords: customer loyalty, service quality, emotional branding

How to Cite: Sari, Novia, Aditya, N. P. \& Pratista, A. S. (2019), Loyalitas Pelanggan Maskapai Penerbangan ditinjau dari Kualitas Layanan dan Emotional Branding, Analitika: Jurnal Magister Psikologi UMA, 11 (2): 98 - 103 


\section{PENDAHULUAN}

Direktur Jenderal Perhubungan Udara mengungkapkan bahwa terjadi peningkatan penumpang pesawat domestik dan internasional sebanyak 9,5\% pada tahun 2017 dengan total 128 juta penumpang (Direktorat Jenderal Perhubungan Udara, 2018). Banyaknya jumlah pengguna jasa pesawat tentu menjadi kesempatan emas bagi maskapai penerbangan untuk menjalankan bisnis penerbangan di Indonesia. Berdasarkan data dari Kementerian Perhubungan Republik Indonesia, terdapat 14 maskapai niaga berjadwal yang beroperasi hingga 2017. Maskapai tersebut saling bersaing untuk menarik dan mempertahankan pelanggan yang loyal.

Pelanggan yang loyal ialah kunci bagi kesuksesan suatu perusahaan (Thakur, 2016). Tingginya angka loyalitas pelanggan tentu dapat memberikan keuntungan yang besar bagi perusahaan dan membantu mempertahankan eksistensi perusahaan ketika permintaan sedang berkurang $\mathrm{COu}$, de Vries, Wiesel \& Verhoef, 2013). Loyalitas pelanggan merupakan kesetiaan pelanggan pada suatu merek yang memungkinkannya untuk terhindar dari daya tarik merek lain dan melakukan pembelian ulang secara teratur serta cenderung akan menawarkan merek tersebut pada orang lain (Lai, 2015).

Kotler \& Keller (2012) mendefinisikan loyalitas pelanggan sebagai konsistensi pelanggan dalam menggunakan dananya untuk membeli produk/layanan yang berasal dari merek atau perusahaan penyedia yang sama. Loyalitas pelanggan dapat dilihat melalui tiga perspektif, yaitu perspektif sikap, perilaku, dan integratif (Tjiptono \& Diana, 2015). Adapun tiga aspek yang disusun Kotler \& Keller (2012) untuk mengukur loyalitas pelanggan, antara lain: (1) Word of mouth (merekomendasikan kepada orang lain); (2) Reject another (menolak merek lain); dan (3) Repeat purchasing (melakukan pembelian berulang).

Penelitian terdahulu menunjukkan bahwa salah satu faktor yang memengaruhi loyalitas pelanggan adalah kualitas layanan (Wiharyo \& Budiarti, 2017; Meitiana, 2014). Kualitas layanan adalah ukuran penilaian terhadap layanan yang diberikan, apakah mampu memenuhi ekspektasi pelanggan atau tidak (Lewis \& Booms dalam Tjiptono \& Chandra, 2016).

Sangadji \& Sopiah (2013) menjelaskan bahwa kualitas layanan yang baik dari suatu perusahaan dapat menimbulkan perasaan puas dalam diri pelanggan yang kemudian mampu meningkatkan loyalitas pelanggan. Lima dimensi yang kualitas layanan yang disusun oleh Parasuraman, Zeithaml \& Berry, antara lain reliability atau keandalan, responsiveness atau daya tanggap, assurance atau jaminan, empathy atau empati, dan tangible atau wujud fisik (dalam Zeithaml, Bitner \& Gremler, 2013)

Selain itu, faktor lain yang dapat memengaruhi loyalitas pelanggan adalah emotional branding. Penelitian Devina \& Andreani (2015) menunjukkan bahwa terdapat hubungan positif antara emotional branding dengan loyalitas pelanggan. Emotional branding adalah saluran yang menghubungkan pelanggan dan perusahaan beserta produk dari perusahaan tersebut secara tidak sadar melalui hubungan emosional yang positif (Gobe, 2005).

Pelanggan harus memiliki emosi yang positif terhadap suatu merek sebelum melakukan pembelian sehingga hubungan 
emosional dengan pelanggan harus dijadikan pondasi utama dalam strategi pemasaran yang inovatif (Roberts, 2004). Gobe (2005) menyebutkan empat aspek emotional branding, yaitu hubungan, pengalaman panca indera, imajinasi, dan visi.

Heskett dalam Lovelock, Wirtz \& Mussry (2011) mengatakan bahwa penyediaan layanan yang berkualitas dan penerapan emotional branding oleh maskapai penerbangan mampu membuat pelanggan merasa puas dan senang terhadap perusahaan tersebut sehingga menimbulkan perilaku pembelian ulang. Harapan yang terbiasa dipenuhi oleh suatu perusahaan akan membuat pelanggan menjadi terikat terhadap perusahaan tersebut sehingga loyalitas pelanggan dapat tercapai dan perusahaan pesaing tidak dapat mempengaruhi pelanggan dengan mudah (Rossiter \& Bellman, 2012).

Namun, berdasarkan hasil studi pendahuluan yang dilakukan peneliti pada mahasiswa, diketahui bahwa alasan mereka loyal terhadap suatu maskapai ialah harga yang relatif murah dan ketersediaan rute. Hal ini berbeda dengan hasil beberapa penelitian sebelumnya. Oleh karena itu, penelitian ini dilakukan untuk: (1) mengetahui adanya hubungan antara kualitas layanan dan emotional branding dengan loyalitas pelanggan; (2) mengetahui adanya hubungan antara kualitas layanan dan loyalitas pelanggan; dan mengetahui adanya hubungan antara emotional branding dengan loyalitas pelanggan maskapai penerbangan.

\section{METODE PENELITIAN}

Penelitian ini dilakukan pada mahasiswa aktif program sarjana FK UNS yang merupakan penumpang pesawat rute domestik kelas ekonomi dan telah menggunakan jasa maskapai penerbangan yang sama minimal sebanyak dua kali hingga tahun 2018. Populasi penelitian ini berjumlah 198 orang dengan 69 orang sebagai sampel yang dipilih menggunakan simple random sampling.

Peneliti melakukan pengukuran terhadap tiga variabel, yaitu variabel loyalitas pelanggan sebagai variabel terikat dan variabel kualitas layanan dan emotional branding sebagai variabel bebas. Skala loyalitas pelanggan dalam penelitian ini disusun berdasarkan aspek yang dikemukakan Kotler \& Keller (2012), yaitu mereferensikan kepada orang lain, menolak daya tarik produk pesaing dan pembelian berulang yang terdiri dari 7 aitem pernyataan dengan koefisien reliabilitas $(\alpha)$ 0,755 . Skala kualitas layanan disusun dengan memodifikasi skala SERVQUAL yang telah disusun oleh Parasurama, dkk (1988) yang terdiri dari 21 aitem dengan koefisien reliabilitas $(\alpha)$ 0,941. Skala emotional branding mengacu pada aspek yang dikemukakan oleh Gobe (2005) yang terdiri dari hubungan, pengalaman panca indera, imajinasi dan visi yang terdiri dari 21 aitem dengan koefisien reliabilitas $(\alpha)$ 0,884.

Data penelitian dianalisis menggunakan teknik analisis regresi berganda dengan bantuan software SPSS 24 for windows.

\section{HASIL DAN PEMBAHASAN}

Sebelum melakukan uji hipotesis, peneliti melakukan uji asumsi dasar dengan SPSS. Hasil uji normalitas KolmogorvSmirnov menunjukkan bahwa ketiga variabel berdistribusi normal dengan nilai signifikansi 0,200 ( $p>0,05)$. Sedangkan, uji 
linearitas dengan test of linearity pada masing-masing variabel bebas dengan variabel terikat menunjukkan nilai signifikansi $0,000(\mathrm{p}<0,05)$. Setelah kedua ujji asumsi dasar terpenuhi, dilakukan uji hipotesis. Adapun hasil analisis regresi berganda untuk menguji ketiga hipotesis peneliti disajikan pada tabel berikut.

Tabel 1. Analisis Regresi Berganda

\begin{tabular}{lrrrrr}
\hline \multicolumn{7}{c}{ ANOVA } \\
\hline Model & Sum of & df & Mean & F & Sig. \\
& Squares & & Square & & \\
\hline 1. Regression & 329,19 & 2 & 164,5 & 13, &, 0 \\
& 4 & & 97 & 348 & 00 \\
& & & & & b \\
\hline Residual & 813,87 & 66 & 12,33 & & \\
\multicolumn{7}{c}{9} & & 1 & & \\
\hline Total & 1143,0 & 68 & & & \\
& 72 & & & &
\end{tabular}

Tabel 1 membuktikan bahwa terdapat hubungan antara kualitas layanan dan emotional branding dengan loyalitas pelanggan maskapai penerbangan pada mahasiswa FK UNS ( $p=0,000, p<0,05)$. Adapun koefisien determinasi (R Square) sebesar 0,288 (lihat Tabel 2). Hasil ini menunjukkan bahwa persentase sumbangan pengaruh kualitas layanan dan emotional branding secara bersama sama mempengaruhi loyalitas pelanggan maskapai sebesar 28,8\%. Sisanya sebesar $71,2 \%$ merupakan pengaruh dari berbagai variabel atau factor lain yang tidak termasuk dalam penelitian ini.

Tabel 2. Analisis Koefisien Korelasi

\begin{tabular}{llccc}
\hline \multicolumn{4}{c}{ Model Summary } \\
\hline \multicolumn{4}{c}{ Adjusted } \\
Model & $\mathrm{R}$ & $\mathrm{R}$ Square & Square & $\begin{array}{c}\text { Std. Error of the } \\
\text { Estimate }\end{array}$ \\
\hline 1 &, $537^{\mathrm{a}}$ &, 288 &, 266 & 3,51162 \\
\hline $\begin{array}{l}\text { a. Predictors: (Constant), Emotional Branding, Kualitas } \\
\text { Layanan }\end{array}$
\end{tabular}

Penelitian ini melengkapi penelitian terdahulu yang dilakukan untuk mengetahui hubungan antar variabel secara parsial. Seperti yang dijelaskan oleh Tjiptono (2007), layanan berkualitas yang dapat memenuhi harapan pelanggan dapat menumbuhkan perasaan puas dan mendorong mereka untuk menggunakan kembali produk/jasa yang sama. Apabila hal ini dipadukan dengan penerapan strategi emotional branding yang mampu memahami dan merepresentasikan harapan pelanggan, maka ikatan afeksi dengan pelanggan dapat terwujud (Atkin, dalam Thompson, dkk, 2006). Perusahaan yang membangun hubungan emosional yang baik dengan pelanggan dapat menciptakan loyalitas dalam diri mereka dengan mengubah kebutuhan menjadi keinginan (Gobe, 2005). Adanya fasilitas yang disediakan maskapai untuk memenuhi kebutuhan pelanggan dengan cara yang diinginkan dapat menciptakan ketergantungan dalam diri mereka terhadap maskapai tersebut (Morrison \& Crane, 2007).

Selain itu, hasil analisis juga menunjukkan bahwa tidak terdapat hubungan yang signifikan antara kualitas layanan dengan loyalitas pelanggan $(p=0,111)$ serta emotional branding dengan loyalitas pelanggan $(\mathrm{p}=0,172)$ secara parsial (lihat Tabel 3).

Tabel 3. Analisis Hubungan Parsial

\begin{tabular}{|c|c|c|c|c|c|c|c|c|}
\hline \multirow[b]{3}{*}{ Model } & \multicolumn{5}{|c|}{ Coefficients $^{\mathrm{a}}$} & \multirow{2}{*}{\multicolumn{3}{|c|}{ Correlations }} \\
\hline & \multicolumn{2}{|c|}{$\begin{array}{c}\text { Unstandardized } \\
\text { Coefficients }\end{array}$} & $\begin{array}{c}\text { Standard } \\
\text { ized } \\
\text { Coefficie } \\
\text { nts } \\
\end{array}$ & & & & & \\
\hline & B & $\begin{array}{l}\text { Std. } \\
\text { Error }\end{array}$ & Beta & $\mathrm{T}$ & Sig. & $\begin{array}{c}\text { Zeroo } \\
\text { rder }\end{array}$ & $\begin{array}{c}\text { Partia } \\
1\end{array}$ & Part \\
\hline \multirow{3}{*}{$\begin{array}{c}\text { (Constant } \\
\text { ) } \\
\text { Kualitas } \\
\text { Layanan } \\
\text { Emotional }\end{array}$} & 7,006 & 2,938 & & 2,384 &, 020 & & & \\
\hline & & & & & & & & \\
\hline &, 101 & ,062 &, 302 & 1,617 &, 111 &, 517 & , 195 &, 168 \\
\hline $\begin{array}{l}\text { Emotional } \\
\text { Branding }\end{array}$ &, 161 &, 117 &, 258 & 1,382 &, 172 &, 510 & , 168 &, 144 \\
\hline
\end{tabular}

Hasil ini mengindikasikan bahwa apabila program pelayanan berdiri sendiri tanpa memberikan perasaan emosional pada pelanggan (emotional branding) tidak dapat mempengaruhi loyalitas pelanggan 
maskapai penerbangan. Begitupula dengan emotional branding yang tidak didukung oleh kualitas layanan juga kurang dapat mempengaruhi loyalitas pelanggan maskapai penerbangan. Hal ini memberikan peluang kepada maskapai penerbangan untuk menciptakan program program pelayanan yang berkualitas dan memiliki emotional branding agar dapat meningkatkan loyalitas pelanggan.

Karakteristik subjek penelitian ini adalah mahasiswa yang sedang berada pada masa perkembangan dewasa awal. Menurut Santrock (2012), beberapa ahli mengatakan bahwa pada masa ini, idealisme seseorang cenderung menurun dan digantikan dengan pemikiran yang lebih realistis dan pragmatis.

Hal itu dapat dihubungkan dengan adanya loyalitas palsu (spurious loyalty) seperti yang dikemukakan oleh Dick \& Basu (dalam Tjiptono, 2007). Spurious loyalty ialah kesetiaan pelanggan yang terlihat dalam perilaku pembelian ulang dengan sikap yang lemah dikarenakan faktor situasional yang mendorong pelanggan untuk melakukan pembelian. Misalnya, adanya potongan harga, ketersediaan rute yang ditawarkan, jadwal penerbangan yang tersedia. Dengan demikian, dapat dipahami bahwa mahasiswa cenderung memilih maskapai dengan mempertimbangkan faktor situasional mereka secara realistis dan praktis.

Selain itu, juga terdapat perbedaan antara loyalitas pelanggan yang merupakan anggota dan bukan anggota dari loyalty program $(p<0,05)$. Pelanggan yang memiliki keanggotaan maskapai memiliki loyalitas yang lebih tinggi daripada yang bukan merupakan anggota. Kepuasan dan kemudahan yang ditawarkan oleh loyalty program mampu mempengaruhi loyalitas pelanggan (Ifca, 2015).

Oleh karena itu, maskapai penerbangan dapat menyediakan kualitas layanan yang baik dengan emotional branding yang mampu menarik pelanggan secara bersamaan. Kedua hal ini dapat diwujudkan melalui promosi, inovasi, dan/atau variasi pelayanan yang dapat dirasakan pelanggan. Selain itu, pengguna jasa maskapai juga perlu menjadikan kedua variabel ini sebagai pertimbangan dalam pemilihan maskapai untuk merasakan pengalaman penerbangan yang menguntungkan dan memuaskan secara fisik maupun psikis.

\section{SIMPULAN}

Berdasarkan penelitian yang telah dilakukan, dapat disimpulkan bahwa terdapat hubungan yang signifikan antara kualitas layanan dan emotional branding dengan loyalitas pelanggan maskapai penerbangan $(p<0,05)$. Hal ini berarti semakin baik kualitas layanan yang diberikan serta emotional branding yang diterapkan secara bersama-sama mampu meningkatkan loyalitas pelanggan maskapai penerbangan. Akan tetapi, secara parsial tidak ditemukannya hubungan yang signifikan antara kualitas layanan maupun emotional branding dengan loyalitas pelanggan maskapai penerbangan. Sumbangan pengaruh kualitas layanan dan emotional branding secara bersama sama mempengaruhi loyalitas pelanggan maskapai sebesar 28,8\%. Sisanya sebesar 71,2\% merupakan pengaruh dari berbagai variabel atau factor lain yang tidak termasuk dalam penelitian ini. 


\section{DAFTAR PUSTAKA}

Devina, R. \& Andreani, F. (2015). Analisa pengembangan strategi emotional branding dalam membangun loyalitas pelanggan Garuda Indonesia Airlines. Jurnal Hospitality dan Manajemen Jasa.

Direktorat Jenderal Perhubungan Udara. (2018). Produksi Meningkat, Penerbangan Nasional Siap Mendukung Pertumbuhan Perekonomian dan Pariwisata Nasional. Diunduh di http://hubud.dephub.go.id/?id/news/detail/3 497.

Gobe, M. (2005). Emotional Branding: Paradigma Baru untuk Menghubungkan Merek dengan Pelanggan. Terj. Mahendra, B. Jakarta: Penerbit Erlangga.

Kotler, P. \& Keller, K. L. (2012) Marketing Management, $14^{\text {th }}$ Global edition. London: Pearson Education.

Lai, I. K. W. (2015). The roles of value, satisfaction, and commitment in the effect of service quality on customer loyalty in Hongkongstyle tea restaurants. Cornell Hospitality Quarterly, 56(1).

Lovelock, C., Wirtz, J. \& Mussry, J. (2011). Pemasaran Jasa - Perspektif Indonesia, jilid 2, edisi ke-7. Terj. Wulandari, D. \& Putera, D. B. Jakarta: Penerbit Erlangga.

Meitiana. (2014). Pengaruh kualitas layanan terhadap loyalitas melalui kepuasan pelanggan pengguna jasa transportasi udara rute Palangkaraya - Jakarta. Jurnal Sains Manajemen (JSM), 3(1).

Morrison, S. \& Crane, F. G. (2007). Building the service brand by creating and managing an emotional branding experience. Brand Management, 14(5).

Ou, Y. C., de Vries, L., Wiesel, T. \& Verhoef, P. C. (2013). The role of consumer confidence in creating customer loyalty. Journal of Service Research

Rido, E. \& Wibowo, S. (2016). Pengaruh experiential marketing, emotional branding dan citra merek terhadap loyalitas merek (survei konsumen operator Simpati di Yogyakarta), $7(2)$.

Roberts, K. (2004). Lovemarks: The Future Beyong Brands. New York: Power House Books.

Rossiter, J. \& Bellman, S. (2012). Emotional branding pays off: how brands meet share of requirements through bonding, companionship, and love. Journal of Advertising Research, 52(3).

Sangadji, E. M. \& Sopiah. (2013). Perilaku Konsumen: Pendekatan Praktis disertai
Himpunan Jurnal Penelitian. Yogyakarta: Andi.

Santrock, J. W. (2012). Perkembangan Masa Hidup, jilid 2, edisi ke-13. Terj.Widyasinta, B. Jakarta: Penerbit Erlangga.

Thakur, R. (2016). Understanding customer engagement and loyalty: a case of mobile devices for shopping. Journal of Retailing and Consumer Services, 32.

Thompson, C. J., Rindfleisch, A. \& Arsel, Z. (2006). Emotional branding and the strategic value of the doppelganger brand image. Journal of Marketing, 70.

Tjiptono, F. (2007). Pemasaran Jasa. Malang: Bayumedia Publishing.

Tjiptono, F. \& Chandra, G. (2016). Service Quality $\mathcal{E}$ Satisfaction, edisi ke-4. Yogyakarta: Penerbit Andi.

Tjiptono, F. \& Diana, A. (2015). Pelanggan Puas? Tak Cukup!. Yogyakarta: Penerbit Andi.

Variano, V. (2017). Pengaruh citra merek, harga, dan kualitas layanan terhadap loyalitas merek konsumen kereta api. Agora, 5(3).

Wiharyo, S. \& Budiarti, A. (2017). Kepuasan sebagai mediasi pengaruh kualitas layanan dan harga terhadap loyalitas penumpang Citilink. Jurnal Ilmu dan Riset Manajemen, 6(3).

Zeithaml, V. A., Bitner, M. J. \& Gremler, D. D. (2013). Service Marketing: Integrating Customer Focus across The Firm, $6^{\text {th }}$ edition. Singapore: Mc Graw Hill.

Rahmathulla, V.K. Das P. Ramesh, M. \& Rajan, R.K. (2007). Growth Rate Pattern and Economic Traits of Silkworm Bombyx mori, L under the influence of folic acid administration. J. Appl. Sci. Environ. Manage. 11(4): 81-84 